\title{
Use of humour in medical teaching: A scientific basis
}

\author{
Vivek Kirpekar \\ Professor, Dept. of Psychiatry, N.K.P. Salve Institute of Medical Sciences, Nagpur, Maharashtra, India
}

Corresponding Author:

Email: vivek.kirpekar@gmail.com

\section{Introduction}

The perception and the creation of humor is possibly the most complex of all human activities and behaviors. Humor is defined as "the kindly contemplation of the incongruities of life and the artistic expression thereof'. This definition of humor implies that most forms of humor are based on incongruity, the juxtaposition of the 'expected with the unexpected'. Humorous material typically has three components - 1) a commonly understood situation. 2) a build-up of anticipation, suspense or tension and 3) an unexpected twist, response or punchline. ${ }^{1}$

Freud's psychoanalytical view says that it is a response to stress with release of psychic energy and resulting anxiety reduction. Jokes can be harmless or more purposeful. Freud mentioned humor as a mean of making comment while avoiding censorship and recognized as a method to relieve tensions induced by society. $^{2}$

Unfortunately, students often view many of their college classes as boring, difficult, and stressful. ${ }^{3}$ Teaching effectively requires imagination and creativity to turn students on by turning negative perceptions off. Using humor can be a successful teaching tool for that purpose.

In teaching institutes, professors frequently contend that teaching is a serious type of activity and they are not supposed to be entertainers or use humor. They view humor as frivolous, undignified and demeaning to the profession. Professors are generally not trained in the use of humor as it is not part of any curriculum.

Various physiological and psychological benefits are believed to be associated with laughter and/or humor. Some of these physiological benefits include muscle relaxation, stimulated circulation, improved respiration and exercise of the lungs and chest muscles, increased production of the body's natural pain killers called endorphins as well as lowering of pulse rate and blood pressure. For those who don't like to exercise, laughter has even been suggested as a possible extremely tempting alternative. ${ }^{1}$
Positive psychological effects of laughter include reduced anxiety \& stress, greater self-esteem, and increased self-motivation. ${ }^{1}$ Humor is understood to build confidence, improve productivity, heighten interest, reduce boredom and encourage divergent thinking, yet it has been difficult to establish positive value for humor in helping students learning.

Some authors suggested the use of humor as a business management tool that promotes a productive work environment, ${ }^{4}$ as an effective health care tool [5] and as a possible tool to improve interpersonal relationships. ${ }^{6}$

While there are noted physiological and psychological benefits (as above) associated with humor, the one main reason for using humor in the classroom is to improve student learning. The creative development and expression of humor in the classroom deals with "how" to teach, not "what" to teach. The use of humor as a teaching tool if effective, will increase the amount of "what" is taught that is learnt by students.

The use of humor in the classroom can help to create a more positive learning environment by breaking down barriers to communication between the professor and the students. Teacher is perceived as a human and Humor builds rapport between the students and the teacher. Students will be less intimidated and less inhibited about asking questions or making comments. Humor can help students retain subject matter, especially if the humor reinforces the class material. The use of humor may give students a reason (hopefully another reason) to attend class. While no substitute for substance, humor can create a more positive environment, fun, increase in interest and promotes overall class attendance and student learning.

Other reported benefits of humor in the classroom ${ }^{7}$ include increased comprehension and cognitive retention (presumably due to less stress and anxiety), reduced student negativism or hostility regarding potentially confrontational issues (e.g. grading) in the classroom as well as improved student's attitude toward the subject and the instructor. Students expect the professor to be a 
teacher and an educator first but are likely to prefer the professors who show that they have a sense of humor. Some methods of how to use humor in teaching are as follows:

Quotes: Quotes of famous people, yourself, students, etc. often provide one of the simplest ways to introduce humor into a lecture.

Cartoons: Like quotes, cartoons are easy to find (newspapers, magazines, etc.) easy to use (make enlarged overhead) and self-explanatory

The scope of the use of humor in medicine includes: (i) undergraduate, postgraduate and continuing education of medical and other health professionals, (ii) patients' education, (iii) public education. ${ }^{2}$ Humor is not a substitute for clinically competent medical care, but it can be a powerful and delightful adjunct to patient therapy and rapport. ${ }^{8}$

Modern educational theory highlights the importance of interactivity, involvement of the audience who should be stimulated to think and learn and the presenter should be responsive to those reactions.

A strong positive correlation exists between class attendance and student performance ${ }^{11}$ Motivation and curiosity are cornerstones for learning and one can leverage that energy by using the extra credit of humor as a place to flip a lesson. ${ }^{12}$

\section{References}

1. Berk, Ronald A. 1998. Professors are From Mars, Student are From Snickers, Madison, WI: Mendota Press. Hill, Deborah J. 1988. Humor in the Classroom: A Handbook for Teachings (and Other Entertainers!). Springfield

2. Ziegler JB. Use of humor in medical teaching. Medical Teacher 1998;20(4):341-8.

3. Deiter R. The Use of Humor as a Teaching Tool in the College Classroom. NACTA Journal 2000;6:20-8.

4. Kushner ML. The Light Touch: How to Use Humor for Business Success 1990. New York: Simon and Schuster.

5. Clifford, Christine. Not Now... I'm Having a No Hair Day, Duluth, MN: Pfeifer-Hamilton Publishers 1996.

6. Sidey H. A Sense of Humor is No Joke. Commencement address, Iowa State University. Ames, IA 1994.

7. Hill DJ. 1988. Humor in the Classroom: A Handbook for Teachings (and Other Entertainers!). Springfield, IL: Charles C. Thomas. 1998.

8. Goodman JB. Laughing matters: taking your job seriously and yourself lightly. JAMA 1992;267, p. 1858.

9. Brown G, Atkins M. Effective Teaching in Higher Education. 1988. (London, Routledge).

10. Ramsden P. Learning to teach in higher education. (Ed) 1992. (London, Routledge).
11. 11. David J. Burns. How Can Students Improve their Performance? An examination of possible correlates. Accessed on 13th May 2018. from http://www.businesseducationdigestfoundation.org/res ources/Burns\%20edits.pdf .

12. http://www.facultyfocus.com/articles/instructionaldesign/looking-for-flippable-moments-in-your-class. Accessed on $12^{\text {th }}$ May 2018. 